\title{
Performance evaluation of developed reciprocating type cumin cleaner cum grader
}

K.R. JETHVA AND A.K. VARSHNEY

Received : 28.11.2014; Revised : 03.08.2015; Accepted : 02.09.2015

See end of the Paper for authors' affiliation

Correspondence to :

\section{K.R. JETHVA}

Department of Processing and Food Engineering, College of Agricultural Engineering and Technology, Anand Agricultural University, Dholakuva, GODHRA (GUJARAT) INDIA

Email : krjethva78@aau.in;

kamaljethva@gmail.com
-ABSTRACT : India is famous for its pet name in the world of agricultural as the 'home of spices'. India grows 47 out of 70 varieties of spices grown in different parts of the world. Cumin seeds it comes from the field contain foreign matter like weed seeds, stems, leaves, broken seeds, stones, dirt, etc. These foreign matters must be removed to increase quality of seed in the market, storage period of seed, cost of selling and net income to the farmers as well as sellers and to perform different kinds of post harvest operations. Cleaning and grading of cumin in the marketing yard is time consuming and laborious operation because large quantity is to be handled. Some of the big traders used mechanical cleaners and graders, but the initial investment required in the purchasing of such machinery is quite high. Efforts were made to develop a low cost machine that can clean and grade the seed of cumin and can be utilized for the above operation at low investment. Effects of different machine operating parameters on its performance i.e. feed rate, speed and screen slope were evaluated for cleaning efficiency. For getting best cleaning efficiency and low power consumption, the machine should be operated at $50 \mathrm{~kg} / \mathrm{h}$ feed rate, $150 \mathrm{rpm}$ and 7-degree slope. The cost of cleaning is Rs. 0.31/-

- KEY WORDS : Cumin, Cleaner cum grader, Cleaning efficiency, Power consumption

- HOW TO CITE THIS PAPER : Jethva, K.R. and Varshney, A.K. (2015). Performance evaluation of developed reciprocating type cumin cleaner cum grader. Internat. J. Agric. Engg., 8(2) : 151-159. 